\title{
Racial inequality and the implementation of emergency management laws in economically distressed urban areas
}

\author{
Shawna J. Lee PhD, MSW, MPP ${ }^{\mathrm{a}, *}$, Amy Krings PhD, MSW ${ }^{\mathrm{b}}$, Sara Rose MSW ${ }^{\mathrm{a}}$, Krista Dover MSW ${ }^{\mathrm{a}}$, \\ Jessica Ayoub MSW ${ }^{\text {a }}$, Fatima Salman MSW ${ }^{\mathrm{a}}$ \\ a University of Michigan School of Social Work, 1080 S University Ave, Ann Arbor, MI 48109, United States \\ b Loyola University Chicago School of Social Work, 111 E Pearson St, Chicago, IL 60611, United States
}

\section{A R T I C L E I N F O}

\section{Article history:}

Received 9 March 2016

Received in revised form 22 August 2016

Accepted 23 August 2016

Available online 24 August 2016

\section{Keywords:}

Environmental justice

Racism

Social policy

Social services

Public policy

Detroit

Public health

Child welfare

Flint water crisis

\begin{abstract}
A B S T R A C T
This study examines the use of emergency management laws as a policy response to fiscal emergencies in urban areas. Focusing on one Midwestern Rust Belt state, we use a mixed methods approach - integrating chronology of legislative history, analysis of Census data, and an ethnographic case study - to examine the dynamics of emergency management laws from a social justice perspective. Analysis of Census data showed that emergency management policies disproportionately affected African Americans and poor families. Analysis indicated that in one state, $51 \%$ of African American residents and $16.6 \%$ of Hispanic or Latinos residents had lived in cities that were under the governance of an emergency manager at some time during 2008-2013, whereas only $2.4 \%$ of the White population similarly had lived in cities under emergency management. An ethnographic case study highlights the mechanisms by which an emergency manager hindered the ability of residents in one urban neighborhood, expected to host a large public works project, to obtain a Community Benefits Agreement intended to provide assistance to residents, most of whom were poor families with young children. We conclude with a discussion of how emergency management laws may impact social service practice and policy practice in urban communities, framed from a social justice perspective. We argue that these are not race neutral policies, given clear evidence of race and ethnic disparities in their implementation.
\end{abstract}

(c) 2016 Elsevier Ltd. All rights reserved.

\section{Introduction}

The 2007-2009 economic recession was a period of fiscal crisis that deeply affected state and local governments across the country. Governments responded to revenue loss and poor economic conditions through various austerity measures, among them raising taxes, reducing or privatizing public services, declaring bankruptcy, or implementing some form of state receivership (Anderson, 2011; Anderson, 2012; Bowman, 2013; Coe, 2008; Kimhi, 2008). This article analyzes the increasing use of emergency management (EM) laws to respond to fiscal crises and demonstrates how EM laws can have downstream impacts on the health and wellbeing of children and families. Most commonly, EM laws are passed by state legislatures. When a municipal-level fiscal emergency arises, EM laws permit state officials, such as the governor, to appoint a receiver, state agency, or financial control board to oversee local (city) government. In some cases, these laws shift

\footnotetext{
Abbreviations: ACS, American Community Survey; CBA, Community Benefits Agreement; EM, emergency management; US, United States.

* Corresponding author.

E-mail address: shawnal@umich.edu (S.J. Lee).
}

decision-making authority from local elected officials, such as a mayor, city council, or school board, to a single non-elected state appointee, called an emergency manager. Emergency managers often have considerable autonomy over fiscal decisions and can play a pivotal role in developing and implementing new financial and operations plans for the city (Anderson, 2012; Loh, 2015). This paper discusses the implementation of EM laws within the State of Michigan, in part because Michigan has used EM laws more extensively than any other state. Beginning in 2008, 10 cities in Michigan were under emergency management and had an emergency manger in place (see Table 1 ).

In this paper, we begin by situating EM laws within a broader philosophy of austerity politics. We discuss how EM reduces opportunities for local democratic decision-making as well as public investment. We present analysis of Census data that shows that poor individuals and racial minorities live under EM more often than more affluent or white residents. Thus, less powerful groups absorb the costs of EM. We conclude with a case study that describes the mechanics through which EM minimizes local accountability and, ultimately, the provision of public services. We argue that these laws influence the wellbeing of children and families, particularly within economically distressed urban areas, in ways that are problematic and, for the most part, have been ignored. 
Table 1

Michigan Emergency Management Timeline and City Demographic Information.

\begin{tabular}{|c|c|c|c|c|c|c|}
\hline Year EM Appointed & City & Pop. Total & $\begin{array}{l}\text { Black or African American } \\
\mathrm{N}(\%)\end{array}$ & $\begin{array}{l}\text { Hispanic or Latino } \\
\mathrm{N}(\%)\end{array}$ & $\begin{array}{l}\text { White/ Non-Hispanic } \\
\text { N (\%) }\end{array}$ & $\begin{array}{l}\text { \% Living Below Federal } \\
\text { Poverty Level }\end{array}$ \\
\hline 1988 & Ecorse $^{\mathrm{a}}$ & 12,180 & $4,760(39.1)$ & $820(6.7)$ & $6,459(53.0)$ & 25.6 \\
\hline 1988 & Hamtramck $^{\mathrm{a}}$ & 18,372 & $2,573(14.0)$ & $292(1.6)$ & $15,173(82.6)$ & 25.4 \\
\hline 1989 & River Rouge $^{a}$ & 11,314 & $3,957(35.0)$ & $378(3.3)$ & $6,874(60.8)$ & 29.1 \\
\hline 1990 & Royal Oak Township ${ }^{a}$ & 5,011 & $3,267(65.2)$ & $49(1.0)$ & $1,623(32.4)$ & 21.4 \\
\hline 2000 & Hamtramck $^{\mathrm{b}}$ & 22,976 & $3,430(14.9)$ & $300(1.3)$ & $14,872(60.0)$ & 24.1 \\
\hline 2000 & Highland Park ${ }^{\mathrm{b}}$ & 16,746 & $15,598(93.1)$ & $95(0.6)$ & $688(4.0)$ & 32.1 \\
\hline 2002 & Flint $^{\mathrm{b}}$ & 124,943 & $66,231(53.0)$ & $3,742(3.0)$ & $50,020(40.0)$ & 22.9 \\
\hline 2002 & Ecorse $^{\mathrm{b}}$ & 11,229 & $4,533(40.4)$ & $1,004(8.9)$ & $5,313(47.3)$ & 21.7 \\
\hline 2008 & Three Oaks ${ }^{\mathrm{c}}$ & 2,574 & $26(1.0)$ & $76(3.0)$ & $2,406(93.5)$ & 13.2 \\
\hline 2009 & Highland Park ${ }^{\mathrm{c}}$ & 11,776 & $10,955(93.0)$ & $156(1.3)$ & $347(3.0)$ & 40.3 \\
\hline 2011 & Ecorse $^{c}$ & 9,512 & $4,375(46.0)$ & $1,278(13.4)$ & $3476(36.5)$ & 28.4 \\
\hline 2011 & Pontiac ${ }^{c}$ & 59,515 & $30,384(51.1)$ & $9,835(16.5)$ & $15,815(26.6)$ & 31.7 \\
\hline 2012 & Allen Park ${ }^{\mathrm{c}}$ & 28,210 & $588(2.1)$ & $2,274(8.1)$ & $24,643(87.4)$ & 6.0 \\
\hline 2013 & Benton Harbor ${ }^{c}$ & 10,038 & 8,899 (88.7) & $220(2.2)$ & $641(6.4)$ & 44.8 \\
\hline 2013 & Flint $^{\mathrm{c}}$ & 102,434 & $57,451(56.1)$ & $3,976(3.9)$ & $36,537(35.7)$ & 35.5 \\
\hline 2013 & Detroit $^{\mathrm{C}}$ & 713,777 & $586,573(82.2)$ & $48,679(6.8)$ & $55,604(7.8)$ & 33.9 \\
\hline 2013 & Hamtramck $^{\mathrm{c}}$ & 22,423 & $4,285(19.1)$ & $328(1.5)$ & $11,876(53.0)$ & 37.5 \\
\hline 2013 & Lincoln Park ${ }^{\mathrm{c}}$ & 38,144 & $2,172(5.7)$ & $5,676(14.9)$ & $29,102(76.3)$ & 15.6 \\
\hline
\end{tabular}

Note:

a Data from 1990 Decennial Census.

b Data from 2000 Decennial Census.

c Race and ethnicity data from 2010 Decennial Census; poverty data from the 2009-2013 ACS. We used data from the categories for "White alone/ not Hispanic or Latino"; "Black or African American alone/ not Hispanic or Latino"; and "Hispanic or Latino/ all races". Poverty category was "Families/ income below poverty level," for all family categories.

\subsection{Background: the logic and scope of emergency management policy}

Cities in America's Rust Belt, a region that encompasses Midwestern states such as Michigan, continue to grapple with prolonged economic stagnation and decline that stem from business loss and relocation, among other factors (Alder, Lagakos, \& Ohanian, 2014). In the seminal book on the Origins of the Urban Crisis, Sugrue (2005) demonstrates how industrialized cities, such as Detroit, were especially hard hit after corporate decisions to relocate plants and to automate production shrank industrial employment. The impact of employment loss was especially devastating for African Americans because historical redlining policies restricted financial lending on the basis of race, and restrictive covenants forbade the sale of homes to racial minorities. These factors contributed to highly segregated neighborhoods and lack of geographic mobility for the African American community in particular. Other policies that subsidized the construction of interstates and residential suburbs incentivized continued white flight away from urban areas thus further isolating communities of color, particularly low-income individuals, in urban areas (Massey \& Denton, 1993; Sugrue, 2005). Thus, at the same time that racial minorities began to gain political power in urban areas, their access to financial resources declined. In many Rust Belt cities these changes, combined with ongoing reductions in federal and state revenue-sharing with municipalities and the recent housing foreclosure crisis (Coe, 2008; Kasdan, 2016; Scorsone, 2014), have culminated to create severe, multifaceted municipal economic crises that local leaders found difficult to manage via available policy mechanisms (e.g., raising taxes).

The use of EM laws to respond to financial crises is not a new phenomenon; it began during the Great Depression. In fact, EM laws are relatively common: At least 16 states have some form of EM mechanism, among them Rhode Island, Illinois, Indiana, New Jersey, and Ohio (Scorsone, 2014). Recently the Governor of New Jersey appointed an EM to address a fiscal crisis in Atlantic City, New Jersey (McGeehan, 2015). Several states have special legislation that addresses state intervention in a local fiscal crisis on a case-by-case basis (Anderson, 2012; Scorsone, 2014). Scorsone (2014) discusses in detail the economic factors that activate EM laws. Broadly, these laws may come into effect when a city is at risk of defaulting on debt or pension payments or has insufficient cash to make payroll or bond payments (Scorsone, 2014). The solution to such financial emergencies focuses upon the alleviation of fiscal problems through a reduction in local spending, implemented by a state-appointed emergency manager. Structural problems, such as the loss of revenue through the declines in tax base, population, state revenue sharing, and industrial unemployment, are largely ignored (Fasenfest \& Pride, 2016).

Though EM laws are not a recent development, they are prompting new questions about appropriate policy responses to financial emergencies in distressed urban areas (Anderson, 2012; Scorsone, 2014; Skidmore \& Scorsone, 2011). The attainment of social justice requires both a fair process in which the people who are impacted by policy have influence in shaping it as well as the fair distribution of resources (Reisch \& Garvin, 2016). Using a social justice perspective, we summarize some of the critiques of EM laws and processes.

Procedurally, key components of economic restructuring under EM laws may involve development and implementation of a new financial and operations plan without requiring democratic consent from, or consultation with, the public or its elected officials (Anderson, 2012; Loh, 2015). Thus, some argue that EM laws reflect undemocratic processes that privilege a market-oriented logic that uses technocratic, "expert"driven (i.e., the state-appointed emergency manager) decision-making processes, as opposed to decisions reached by democratically elected city government officials, who are often local residents and at a minimum are accountable to local residents through the democratic voting process (Lewis, 2013). Many question whether it is fair for states to use power to strip mayors and city councils of most of their governing power, as often occurs when EM laws are in effect. Loh (2015) describes EM laws in Michigan as an "unprecedented interruption of elected city government" (pg. 2). In addition, there are concerns that an emergency manager is able to renegotiate, terminate, or modify labor contracts, thus potentially weakening the influence of organized labor (Lewis, 2013).

Distributionally, EM laws require cuts to public expenses in order to balance city budgets. Perhaps the most extreme example of this approach came to light in 2015 as a result of the Flint water crisis. In the Flint case, an emergency manager switched the city's water source from the Detroit-supplied Lake Huron pipeline to an alternative water source supplied by the Flint River-a cost-saving measure that culminated in contaminated water and even lead poisoning among the people of Flint (Hanna-Attisha, LaChance, Sadler, \& Schnepp, 2016). Despite protests from residents, the emergency manager would not allow the 
City to switch back to the Detroit water source, citing, among other factors, the financial costs of doing so.

\subsection{Study rationale}

Embedded in a social justice perspective and using a mixed methods methodology, the present study examines the dynamics of EM laws, focusing-for several reasons-on their implementation in Michigan. Michigan has used EM laws to respond to fiscal crises more extensively than any other state; starting in 2008, 10 Michigan cities were placed under emergency management (see Table 1). Though many states use some form of EM in times of fiscal crises, Scorsone (2014), pg. 5 notes that Michigan has been widely scrutinized for "being among the nation's most aggressive in granting extensive powers to an emergency manager." Michigan's extensive use of EM laws enabled the research team to examine use of EM laws through multiple lenses (e.g., historically, quantitatively, and ethnographically), described in the Method section below. In so doing, this study sheds light on the political processes that gave rise to implementation of EM laws in urban areas in Michigan as well as race and ethnic disparities in the impacts of the EM law.

\section{Method}

Our mixed methods approach utilizes historical policy data gathered from the state of Michigan, analysis of U.S. Census and American Community Survey (ACS) data, and a qualitative case study of a neighborhood community organization in one Detroit neighborhood. We first compiled a chronology of legislative processes that documents the legislative history of EM laws in Michigan from the mid-1980s to the present. Then, we identified 12 Michigan municipalities that have had at least one emergency manager since 1988; several cities have had multiple emergency managers operating at different time points (e.g., Ecorse, Hamtramck, Highland Park and Flint) (see Table 1). We used data gathered by the U.S. Census Bureau and the ACS to examine the demographic characteristics of cities under EM, mainly focusing on racial and ethnic groups and family poverty, to better understand who is most impacted by EM laws.

To complement our historical chronology and quantitative data, we present an ethnographic case study that examines how the dynamics of political decision-making in Detroit changed while under EM, thereby limiting local influence. The case involves a grassroots community organization based in the low-income, industrialized southwest Detroit neighborhood of Delray. Data presented in this case study were collected as part of a broader research project conducted during 2011-2014 and used participant observation, interviews $(n=77)$ with residents, elected officials, social service providers, and lobbyists, as well as media content analysis. Neither the larger community case study nor the community-based campaign was originally focused on the issue of emergency management. However, as the campaign progressed, the state financial takeover of Detroit resulted in (perhaps unintended) consequences that further constrained residents' political influence, effectively blocking their ability to secure local investments that would mitigate environmental health impacts within the host neighborhood. See Krings (2015) for more information on the case and its methodology.

\section{Results}

\subsection{Emergency management legislation in Michigan: chronology of legislation}

The EM system permits state-appointed officials to replace local elected officials, such as city councils or mayors, and to have widespread fiscal authority with limited connection to residents. In this section, we provide a brief policy history of Michigan's Local Financial Stability and
Choice Act of 2012 (Public Act 436; Mich. Comp. Laws $\S$ 141.1541141.1575) - better known as the EM law.

In the state of Michigan, legislation that allows the use of state power to intervene during times of fiscal crises dates from the 1960s. The more immediate predecessor of the current EM law is the 1988 Local Government Fiscal Responsibility Act or Public Act 101 of 1988 (PA 101, repealed 1990; Mich Comp. Laws § 141.1101-141.1118). PA 101 provided the structure that allowed the state to intervene when local municipalities were found to be in financial distress. PA 101 included language that allowed for the governor to assign a local emergency financial manager. This law defined the financial conditions that would trigger state intervention.

PA 101 was followed by the Local Government Fiscal Responsibility Act of 1990 or Public Act 72 (PA 72, repealed 2012; Mich Comp. Laws $\S 141.1201-141.1291)$. PA 72 expanded the scope of EM laws and allowed for state receivership to include public school districts (Bowman, 2013). PA 72 allowed EMs to control financial decisions, for example, revising and creating city budgets and approving spending decisions. Although EMs had considerable fiscal responsibility under PA 72 , governance remained in the hands of local elected officials.

The Local Government and School District Fiscal Accountability Act of 2011 (Public Act 4; Mich Comp. Laws § 141.1501-141.1531) became Michigan's third municipal takeover statute (Bowman, 2013). This legislative effort expanded EM powers beyond financial decision-making. As such, the title was shifted from "emergency financial manager" to "emergency manager" (Bowman, 2013). The title change reflects the expansion of EM powers and shift from emergency financial manager to simply an emergency manager. Under PA 4, emergency managers were able to modify collective bargaining agreements, suspend collecting bargaining for up to five years, remove pension board members, and other changes (Arsen \& Mason, 2013; Bowman, 2013). Furthermore, PA 4 granted the state governor further autonomy in appointing an EM, allowing for the appointment of EMs "without the advice and consent of the senate and without input required from other government officials, elected or appointed" (Bowman, 2013, pg. 7).

PA 4 was passed by the Michigan State Legislature and signed by the governor in six weeks, largely eliminating the potential for voter input. Following its passage, citizens circulated a petition to repeal PA 4 as a referendum on the state ballot. PA 4 was rejected by voters and repealed by popular vote in the General Election of 2012 (Bowman, 2013). As a result of the repeal of PA 4, PA 72 temporarily went back into effect. However, five weeks after PA 4 was repealed by popular vote, the Michigan State Legislature revised and passed a new bill, the Local Financial Stability and Choice Act of 2012 (Public Act 436; Mich. Comp. Laws $\S$ 141.1541-141.1575), which retained the emergency management model of PA 4. PA 436 was approved by the governor and went into effect in March 2013.

\subsection{Race, class, and emergency management: quantitative analysis}

We focus on the-time period beginning in 2008 for several reasons. This time period included an extended period of recovery from the 2007-2008 economic recession and the federal government bail out of the automotive industry. As discussed in the legislative chronology, this time period coincides with substantial expansion of EM powers by state policy makers. Furthermore, during this time period state officials made more extensive use of EM laws than at any other time, with 10 cities under EM, including the historic Detroit bankruptcy negotiations that were conducted under Detroit emergency manager Kevyn Orr. (see Table 1 ).

We used 2010 Census data and 2009-2013 ACS data to examine race and ethnicity, focusing on the three largest race and ethnic groups in Michigan, and family poverty rates of Michigan cities that experienced emergency management intervention beginning in 2008. Overall, as noted in Table 2, based on 2010 Census numbers, the Michigan 
Table 2

Racial Distribution of Emergency Management Laws in Michigan, 2008 - 2013.

\begin{tabular}{|c|c|c|c|c|}
\hline & Total & Black or African American & Hispanic or Latino & White/Non-Hispanic \\
\hline Michigan & $9,883,640$ & $1,383,756(14.0 \%)$ & $436,358(4.4 \%)$ & 7,569,939 (76.6\%) \\
\hline Cities Under EM Only & 998,403 & $705,708(70.7 \%)$ & $72,498(7.3 \%)$ & $180,447(18.1 \%)$ \\
\hline Under EM / Michigan Population & $10.10 \%$ & $51.0 \%$ & $16.6 \%$ & $2.4 \%$ \\
\hline
\end{tabular}

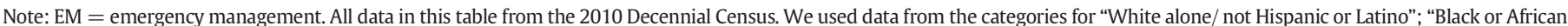
American alone/ not Hispanic or Latino"; and "Hispanic or Latino/ all races".

population was majority non-Hispanic White (76.6\%); $14 \%$ of the population was Black or African American, and $4.4 \%$ was Hispanic or Latino. Based on our analysis (Tables 1 and 2), 10.1\% of all Michigan residents lived in cities that were under emergency management at some point from 2008 - 2013. Of the $10.1 \%$ of Michigan residents under emergency management, $70.7 \%$ were African American and 7.3\% were Hispanic or Latino. By contrast, $18.1 \%$ of the population under emergency management was White. Thus, both African American and Hispanic or Latino populations were overrepresented in cities under EM, whereas Whites were clearly underrepresented.

Furthermore, as seen in Table 2, we examined how the demographic characteristics of those under EM compared to the state level demographic profile. African Americans comprised 14\% of Michigan's population. Yet, compared to their total representation in the Michigan population, 51\% of African Americans in Michigan were under an emergency manager at some point from 2008 - 2013. The Hispanic or Latinos population comprised just $4.4 \%$ of the Michigan population. Yet, the Hispanic or Latino population was also overrepresented, with $16.6 \%$ of all Michigan Hispanic or Latinos under EM at some point during 20082013. In contrast, during the same time period, although non-Hispanic Whites were $76.6 \%$ of Michigan residents, only $2.4 \%$ of Whites in the state were under an emergency manager.

Additionally, ACS data (5-year estimates for 2009-2013) indicated that the poverty level for all families in Michigan was $12 \%$. Cities under EM laws had much higher poverty rates than the state as a whole (Table 1). For example, the poverty levels for families were $37.5 \%$ in Hamtramck, $44.8 \%$ in Benton Harbor, and $40.3 \%$ in Highland Park. Only Allen Park and Three Oaks had family poverty rates that were similar to or lower than the state average. Allen Park's financial hardship resulted not only from the historical trends previously described (relocation of industry, urban sprawl, decline in federal and state revenue sharing), but also from a "failed movie studio development project" (Williams, 2012) from which the small city could not recover.

Finally, it is worth noting that, as indicated in the chronology presented in Table 1, numerous cities (Ecorse, Hamtramck, Highland Park, and Flint) have had more than one bought of emergency management. This suggests that the EM system may not effectively solve the problems that is intended to fix.

\subsection{Community organizing and emergency management: an ethnographic case study}

In Detroit, the EM law was activated in response to a severe and worsening fiscal crisis. According to the Detroit Free Press, following the economic recession the city had $\$ 18$ billion in liabilities; possessed 78,000 blighted buildings; and devoted 4 of every 10 dollars to debt, pensions, and retiree health care rather than necessary city services (Bomey, Gallagher, \& Stryker, 2014). In March 2013, Michigan Governor Rick Snyder appointed Kevyn Orr as the emergency manager of Detroit. In July 2013, Detroit became the largest American city to declare bankruptcy when Orr filed for municipal bankruptcy in U.S. District Court in Detroit (no author, Detroit Free Press, 2014; Zavattaro, 2014). To demonstrate the mechanism through which the EM law curtails local democracy and social welfare provision, we present a case study of a Southwest Detroit neighborhood's Community Benefits Coalition campaign to promote local investment in exchange for hosting a new international border crossing, and how the Detroit emergency manager played a role in thwarting their efforts to obtain a Community Benefits Agreement, or CBA.

Discussion of constructing a new international border crossing bridge to link the United States and Canada dated back to 2008, when a team of representatives from the United States, Canada, Michigan, and Ontario proposed to construct a new border crossing and interstate that would streamline growing international trade. The team acknowledged that the new bridge would result in environmental health impacts within its host community. Although it considered many host neighborhoods up and down the border, the team ultimately decided that the U.S. leg of the crossing would land in the heavily industrialized, low-income southwest Detroit neighborhood of Delray (Krings, 2015).

Following the announcement, many residents stated that they were not surprised by the decision because so many other locally undesirable land uses were already placed in the neighborhood, including the region's wastewater treatment plant. Furthermore, they believed that their neighborhood was targeted because its residents are predominately poor racial minorities who lack political influence (Krings, Spencer, \& Jimenez, 2013). According to the ACS 5-Year Estimates (2009-2013), 17.3\% of Delray residents were Black or African American, $29 \%$ were of Hispanic or Latino origin, and $31 \%$ were White. $21 \%$ of Delray residents were foreign born. Approximately $40 \%$ of Delray households lived in poverty and one-third were female-headed households. Furthermore, the Delray community is young - 29\% of Delray residents are age 19 or younger. Residents of Delray experience some of the poorest health outcomes for children in Michigan. For example, the asthma rate in Southwest Detroit is three times higher than the state average, and its rate of preventable hospitalization among children was the highest in the city (Tanner-White \& Lam, 2010; University of Michigan Urban and Regional Planning Program, 2007; Schlanger, 2016).

While some Delray residents and business owners dreamed that the new bridge would bring investment, others held a litany of concerns. The residents, business owners, and faith leaders who would be displaced by the bridge and customs plaza wondered if eminent domain laws would compensate them adequately and some, particularly the elderly, did not want to be moved. Some viewed the new bridge as an example of environment injustice. Residents who would stay in the neighborhood pointed to the high rates of childhood asthma in the neighborhood and feared that the new bridge, with its attendant rise in traffic, diesel emissions, and noise pollution, would harm the health of children whose lungs were still developing.

Believing that it would be impossible to prevent the new crossing, community stakeholders organized to pursue a community benefits agreement, or CBA. CBAs typically result from a bargain in which a community coalition agrees to support a new development in exchange for investment in the community (Parks \& Warren, 2009). Stakeholders in the community learned about CBAs that were obtained in Los Angeles to mitigate harm related to the L.A. airport and port, for example. Thus, Delray neighborhood residents were optimistic that a CBA could produce local investments in services for children, such as schools and health clinics, as well as affordable housing, access to clear and timely information, and local accountability relating to the project. For 
example, the Community Benefits Coalition advocated for the installation of additional air quality monitoring systems as well as an air conditioning system within the neighborhood's only remaining school.

From its 2008 inception until 2012, Southwest Detroit Community Benefits Coalition lobbied city, state, national, and even Canadian officials for a CBA. In 2012, despite their efforts, Michigan Governor Rick Snyder and Canadian Prime Minister Stephen Harper signed an agreement to build the bridge, without specific local investments. The Community Benefits Coalition's political leverage dwindled and the neighborhood's decline accelerated.

In 2014, a new political opportunity emerged for the coalition. To build the new crossing, Michigan needed to purchase land that the city had obtained through tax foreclosures. Coalition members, in cooperation with their city council member, lobbied the Detroit Mayor and City Council to include a provision in the land sale that the $\$ 1.4$ million sale price would be invested back into Delray. The Detroit City Council unanimously agreed with the plan and passed a bill to sell the city land, on the condition that it included local investments to Delray (Guillen, 2014).

However, following the Detroit City Council's approval of the land sale, Kevyn Orr - who, as noted earlier, had been appointed emergency manager of Detroit in 2013 - proposed an alternative plan that did not include a commitment to Delray. As an emergency manager, Orr and his team were focused on paying down Detroit's fiscal debt. Thus, rather than investing in declining neighborhoods, their main interest was in paying off the city's creditors. Under the Michigan EM law, the actions of the Mayor and City Council were advisory and are not binding; ultimately, Orr was under no obligation, politically or otherwise, to enact the plan approved by Detroit City Council. Under the legislative provisions of the EM law, the emergency manager alone determines the contracts and agreements the City enters into. Ultimately, a state emergency loan board considered the two plans and chose the one proposed by Orr, justifying its decision by stating that under EM law, provisions could not be placed upon the sale of city assets. The Community Benefits Coalition and its city council member were stunned. Not only did the community lose the opportunity for investment through the land sale, the democratic process had been undermined by an unelected emergency manager who prioritized the city's credit over local health and wellbeing (Felton, 2014).

In November 2014, the Detroit bankruptcy was settled in U.S. Bankruptcy Court. In December 2014, Kevyn Orr resigned as EM of Detroit. In 2015, when Orr officially stepped down and the Mayor regained authority, the Community Benefits Coalition returned to the City, again asking for local investment. At the time of publication, some city money has been invested in tearing down blighted buildings within the community and the coalition continues to advocate for investment through other means.

\section{Discussion}

The use of EM laws is increasingly widespread, but they are not well understood by practitioners in social service settings. In this article, we describe EM laws and their implementation during a period of economic distress in one Rust Belt state - Michigan. The purpose of this article is not to argue that fiscal intervention is or was unwarranted in cities governed by EM laws. Indeed, many of the cities - in Michigan and elsewhere - where EM laws have been implemented have suffered from severe, prolonged economic distress that deeply affected the basic functions of city government, to the detriment of the citizens in those areas (Zavattaro, 2014). Rather, our goal was to examine these policies from a social justice perspective, by showing that EM laws have a disproportionate impact on vulnerable and oppressed populations, including racial and ethnic minorities, and families living in poverty. We question how the continued use of EM policies may affect the ability of the urban poor and minorities to exert political power and, ultimately, to promote residents' health and wellbeing. We argue that the continued disenfranchisement of urban populations is a topic of central concern for social service providers working in urban communities with vulnerable and oppressed populations.

Anderson (2012) argues that EM laws reflect “ "democratic dissolution'... changes that suspend local democracy, even though the city remains a legal entity.... [it] preserves the municipal corporation but suspends its government" (Anderson, 2012, pg. 581). Indeed, as we describe in the chronology of EM law legislation, the legislative process that put the EM law into place in Michigan ignored the will of the citizens. When a statewide ballot initiative to repeal PA 4 was approved by the majority of Michigan voters, the Michigan State Legislature circumvented the legislative process and enacted PA 436, which retained the widespread powers of the emergency management process of PA 4, doing so through the use of an Appropriations bill which cannot be subject to repeal through statewide referendum. And, unlike a city mayor or city council, the governor-appointed decision-maker is under no direct mandate to respond to local pressure. In this way, EM laws limit citizen input in favor of an unelected manager and his or her staff, whom, it can be argued, often make decisions motivated by cutting costs rather than promoting the health and wellbeing of residents.

Our analyses of Census data show that EM laws disproportionally affect race and ethnic minority residents of urban areas with higher-thanaverage poverty rates. A startling 51\% of African Americans residing in Michigan have been under the governance of EM laws at some point since 2008. Hispanic or Latinos were also overrepresented relative to the state demographic profile, with $16.6 \%$ of the Hispanic or Latino population under EM even though they were only $4.4 \%$ of the Michigan population. Even more shocking, in a state that is majority non-Hispanic White (76.6\%), only $2.4 \%$ of Whites statewide were ever directly under the governance of an emergency manager during the same time period.

An implication of this descriptive analysis is that a majority of African Americans in Michigan have been denied the local control typically available through democratically elected city council and mayoral authority. These data indicate that it is simply not possible to argue that these policies are "race neutral," as the impact is almost exclusively borne by race and ethnic minority populations in Michigan. When viewed in the context of the legacies of racial discrimination in the U.S. (e.g., Sugrue, 2005), we must question how these policies serve as a structural factor contributing to continued racial inequality and the disenfranchisement and disempowerment of the urban poor and minorities.

Because EM laws are intended to address fiscal crises, it may not be surprising that families living in poverty are also disproportionality affected by EM laws. Nonetheless, the numbers are again striking. Nearly all Michigan cities governed by EM laws had poverty rates for families that were double - and even triple - the state poverty rate for families (12\%). Here again is evidence that the impact of EM laws are disproportionately borne by marginalized groups - including socioeconomically disadvantaged families - who are historically the least able to exert political power.

The case study of Delray is one example of how the system of emergency management affects the health and wellbeing of children and families. Without the Mayor or City Council to advocate on their behalf, the citizens of Delray had little opportunity to leverage CBA investment. In the case of Delray, the CBA included community residents efforts to protect their children's health from the increased pollution that was likely to result from the placement of an international bridge crossing in their neighborhood. Despite residents' efforts, the EM procedures were one factor that blocked their efforts to obtain a CBA. Had they been successful, the CBA would have provided funds to protect children's health from increased pollution associated with the new international bridge crossing. We argue that this is one example of how the system of emergency management removed opportunities for democratic participation in city politics and, in so doing, limited the political 
power of a grassroots group fighting for investments in health and wellbeing.

As noted in the introduction, another example of the impact of such policies on the health and wellbeing of children and families is the Flint water crisis. In an effort to save money, in 2014 the City of Flint switched its water source from the Detroit-supplied Lake Huron pipeline to an alternative water source supplied by the Flint River (Hanna-Attisha et al., 2016). The decision to switch to an alternative water source was made while Flint was under the leadership of an emergency manager appointed by the Michigan governor. The Flint emergency manager played a key role in initiating and approving the decision to switch to an alternative water source. Little consideration was given to protests from Flint City residents nor to the evidence suggesting health-related concerns resulting from the water source switch until a local pediatrician and her colleagues issued a report that documented that the blood lead levels of children in some Flint neighborhoods more than doubled subsequent to the water source switch (Hanna-Attisha et al., 2016). Exposure to environmental contaminants such as lead is likely to contribute to long-term negative ramifications for children's health (Hanna-Attisha et al., 2016; Trentacosta, Davis-Kean, Mitchell, Hyde, \& Dolinoy, 2016). Lead exposure in pregnant women is also linked to fetal death, reduced birth weight, as well as numerous negative health and behavioral outcomes in young children (Hanna-Attisha et al., 2016). Additionally, a recent review describes how contaminants in the physical environment such as lead may alter the development of the growing brain, perhaps contributing to outcomes such as poorer academic outcomes and decreased executive functioning in young children (Trentacosta et al., 2016).

Grassroots organizing and residents' alliances with researchers like Dr. Attisha's report (2016) facilitated the documentation and dissemination of evidence relating to the dangers associated with the Flint water. In October 2015, after 18 months of the EM justifying his refusal to return to the Detroit water system by stating that it was cost prohibitive to do so, the governor approved the decision to switch back to the Detroit water system and, later, he declared a state of emergency due to the lack of clean water in the city. Despite international media attention and widespread concern about the health consequences of lead exposure to Flint children, the Michigan EM law remains in place.

\subsection{Austerity politics and the urban poor}

A larger question is whether EM laws address the underlying economic conditions that created the specific municipal economic crisis (Scorsone, 2014; Zavattaro, 2014). While our study does not address this question, we note that several Michigan cities were governed by EM laws multiple times, suggesting that the implementation of EM laws may not resolve the underlying economic and management conditions that gave rise to a fiscal "emergency" in the first place (Zavattaro, 2014). In terms of the distribution of public resources, rather than addressing global political and economic systems that influence local municipalities and their budgets, emergency management attempts to balance budgets by curtailing local services - ultimately, one could argue, this mistakenly places the blame for fiscal crises on city residents and local government (e.g., calling out the mismanagement of funds) without properly acknowledging the effects of long-standing global economic trends, such as those noted in the introduction (e.g., relocation of jobs away from urban centers, "white flight"), conditions that extend far beyond the control of city residents and local governments. Rather than hurting creditors' bottom line, emergency management offloads costs to the most vulnerable (Peck, 2012). Spending fields that are not defended by powerful constituencies or large voting blocs are especially vulnerable under such conditions, resulting in the default targeting of programs for the poor and marginalized. By cutting public services, governments do not inherently become "leaner" and "more efficient". Rather, eliminating public services including schools, health clinics, streetlights, and parks, risks harming poor children and families and, in cases like Delray, creating a de facto abandonment. This culminates in fewer taxpaying residents and a deeper concentration of poverty. As others have noted, without a sustainable plan to address the economic health of urban areas with longstanding problems (Loh, 2015), it is entirely possible that cities will again fall into fiscal "emergencies" perpetuating the use of EM laws.

\subsection{Study limitations and directions for future research}

Our study is intended as a descriptive analysis of EM law implementation in one Midwestern Rust Belt state. Illinois, Indiana, New Jersey, Ohio, and other states also have EM policies in place. Interstate comparative analysis of these policies is beyond the scope of the current article. Thus, a study limitation is that the experience in Michigan may not be generalizable to conditions in other states. Furthermore, this article does not make causal arguments; rather our analysis observes that beginning in 2009, EM laws were almost exclusively implemented in urban, majority-African American cities. Our ethnographic study also does not seek to make causal arguments. Because there is no counterfactual, it is possible that the same set of decisions that led to the abandonment of the Delray CBA would have been made regardless of the presence of the emergency manager. Future studies may wish to explore EM policies in other states and geographic locations; the application and implementation of EM laws or similar practices in settings other than cities, such as school districts; the perceptions of city residents, e.g., those who are directly impacted by EM laws, of the benefits and costs of emergency management laws and practices; and policy alternatives that do not involve the use of EM laws that would contribute to the fiscal stability of under-resourced urban areas.

\section{Conclusion}

This present article serves as a caution regarding the use of EM laws as a tool to address fiscal emergencies. Although it may be unintentional, these laws limit local political self-determination and have direct implications for the health and wellbeing of low-income children and families-especially those living in communities of color. EM laws hinder local citizens' ability to meaningfully participate in decision-making that directly affects their wellbeing and exerts this influence on precisely the populations with the least power in society-that is, minorities and the urban poor. In the absence of more comprehensive policies to address underlying social inequalities, EM laws are unlikely to be successful in remedying economic distress in urban areas.

\section{Acknowledgements}

This research was supported by a grant to the first author (Lee) from the University of Michigan School of Social Work Learning Community on Poverty and Inequality and by a grant to the second author (Krings) from the University of Michigan Rackham Graduate School Predoctoral Fellowship. We extend sincere appreciation and thanks to Sandra Danziger and Reynolds Farley, who provided enormously valuable feedback on the manuscript. We would also like to thank three anonymous reviewers whose insights and suggestions helped us improve the manuscript.

\section{References}

Alder, S., Lagakos, D., \& Ohanian, L. (2014, August). The decline of the U.S. Rust Belt: A macroeconomic analysis. (Working Paper 14-5). Atlanta: Federal Reserve Bank CQER Working Paper 14-5. Retrieved October 15, 2015 from http://papers.ssrn.com/sol3/ papers.cfm?abstract_id $=2586168$

Anderson, J. (2011). Rightsizing government: The literature and the Detroit experience State and Local Government Review, 43, 224-232. http://dx.doi.org/10.1177/ $0160323 X 11429713$.

Anderson, M. W. (2012). Democratic dissolution: Radical experimentation in state takeovers of local governments. Fordham Urban Law Journal, 39, 577-623 (Retrieved October 15, 2015 from) http://scholarship.law.berkeley.edu/facpubs/1943 
Arsen, D., \& Mason, M. L. (2013). Seeking accountability through state-appointed emergency district management. Educational Policy, 27, 248-278. http://dx.doi.org/10. $1177 / 0895904813475711$.

Bomey, N., Gallagher, J., \& Stryker, M. (2014, November 7). How Detroit was reborn: The inside story of Detroit's historic bankruptcy. Detroit Free Press (Retrieved October 15, 2015 from:) http://www.freep.com/topic/54b59562-6b6b-4b3b-97ad2b9916a5cdbd/detroit-reborn/

Bowman, K. L. (2013). State takeovers of school districts and related litigation: Michigan as a case study [Research Paper No. 11-13]. The Urban Lawyer, 45, 1-19.

Coe, C. K. (2008). Preventing local government fiscal crises: Emerging best practices. Public Administration Review, 68(4), 759-767. http://dx.doi.org/10.1111/j.15406210.2008.00913.x

Detroit Free Press. (2014, November 7). Timeline: Detroit's road through bankruptcy. Retrieved October 13, 2015 from http://www.detroitnews.com/story/news/local/ wayne-county/2014/11/07/timeline-detroits-road-bankruptcy/18654077/

Fasenfest, D., \& Pride, T. (2016). Emergency management in Michigan: Race, class, and the limits of liberal democracy. Critical Sociology, 42(3), 331-334.

Felton, R. (2014, October 1). Detroit Councilwoman requests investigation into top Detroit attorney action in bridge land sale, Detroit Metro Times. Retrieved October 13, 2015 from http://m.metrotimes.com/Blogs/archives/2014/10/01/detroit-councilwomanrequests-investigation-into-top-detroit-attorneys-action-in-bridge-land-sale

Guillen, J. (2014, September 14). Delray wants \$1.4M from land sale to be reinvested in neighborhood, Detroit Free Press. Retrieved September 2, 2015 from http://www. freep.com/story/news/local/michigan/detroit/2014/09/14/delray-wants-14m-fromland-sale-to-be-reinvested-in-neighborhood/15590821/

Hanna-Attisha, M., LaChance, J., Sadler, R. C., \& Schnepp, A. C. (2016). Elevated blood lead levels in children associated with the Flint drinking water crisis: A spatial analysis of risk and public health response. American Journal of Public Health, 106(2), 283-290.

Kasdan, D. O. (2016). Emergency management 2.0: This time, it's financial. Urban Affairs Review, 52(5), 864-882.

Kimhi, O. (2008). Reviving cities: Legal remedies to municipal financial crises. Boston University Law Review, 88(3), 633-684.

Krings, A. (2015). Building Bridges Where There is Nothing Left to Burn: The Campaign for Environmental Justice in a Southwest Detroit Border Community. The University of Michigan.

Krings, A., Spencer, M. S., \& Jimenez, K. (2013). In C. S. Ramanathan, \& S. Dutta (Eds.), Organizing for Environmental Justice: From Bridges to Taro Patches. Routledge: Governance, Development, and Social Work.

Lewis, C. (2013, May 9). Does Michigan's emergency-manager law disenfranchise black citizens? Atlantic monthly (Retrieved October 1, 2015 from) http://www. theatlantic.com/politics/archive/2013/05/does-michigans-emergency-manager-lawdisenfranchise-black-citizens/275639/

Loh, C. G. (2015). The everyday emergency: Planning and democracy under austerity regimes. Urban Affairs Review, 30, 2015. http://dx.doi.org/10.1177/1078087415577639 (Prepublished March)

Massey, D. S., \& Denton, N. A. (1993). American apartheid: Segregation and the making of the underclass. Cambridge, MA: Harvard University Press.
McGeehan, P. (2015, January 22). Christie uses executive order to appoint an emergency manager in Atlantic City. The New York Times. Retrieved March 8, 2016 from http:// www.nytimes.com/2015/01/23/nyregion/christie-uses-executive-order-to-appointan-emergency-manager-in-atlantic-city.html

Mich Comp. Laws § 141.1101-141.1118. Local Government Fiscal Responsibility Act or Public Act 101 of 1988. Repealed 1990.

Mich Comp. Laws $§ 141.1201-141.1291$. Local Government Fiscal Responsibility Act, Act 72 of 1990. Repealed 2012

Mich Comp. Laws § 141.1501-141.1531. Local Government and School District Fiscal Accountability Act, Act 4 of 2011. Rejected by majority of voters, November 2012.

Mich. Comp. Laws § 141.1541-141.1575. Local Financial Stability and Choice Act, Act 436 of 2012.

Parks, V., \& Warren, D. (2009). The politics and practice of economic justice: Community benefits agreements as tactic of the new accountable development movement. Journal of Community Practice, 17(1-2), 88-106.

Peck, J. (2012). Austerity urbanism: American cities under extreme economy. City, 16(6), 626-655.

Reisch, M., \& Garvin, C. D. (2016). Social work and social justice: Concepts, challenges, and strategies. Oxford Press.

Schlanger, Z. (2016, March 30). Choking to death in Detroit: Flint isn't Michigan's only disaster. Newsweek.

Scorsone, E. A. (2014). Municipal fiscal emergency laws: Background and guide to statebased approaches [Working Paper No. 14-21]. Arlington, VA: Mercatus Center at George Mason University July. (Retrieved on October 2, 2015 from) http:// mercatus.org/sites/default/files/Scorsone-Municipal-Fiscal-Emergency.pdf

Skidmore, M., \& Scorsone, E. (2011). Causes and consequences of fiscal stress in Michigan cities. Regional Science and Urban Economics, 41(4), 360-371. http://dx.doi.org/10. 1016/j.regsciurbeco.2011.02.007.

Sugrue, T. (2005). The origins of the urban crisis: Race and inequality in postwar Detroit. Princeton, NJ: Princeton University Press.

Tanner-White, K., \& Lam, T. (2010). Database: Toxic ZIP code rankings. Detroit Free Press June 20. (Retrieved from) http://www.freep.com/article/20100620/NEWS06/ $100619021 /$ ?appSession $=169121870492172$

Trentacosta, C. J., Davis-Kean, P., Mitchell, C., Hyde, L., \& Dolinoy, D. (2016). Environmental contaminants and child development. Child Development Perspectives.

University of Michigan Urban and Regional Planning Program (2007,). A local response to the Detroit river international crossing: recommendations to guide a community benefits agreement. (Retrieved on March 9, 2016 from) http://taubmancollege. umich.edu/pdfs/student_work/planning/DelrayCommunityBenefitsAgreement.pdf

Williams, C. (2012). Allen Park latest Michigan city to get emergency manager. Crain's Detroit business. Crain Communications, Inc October 26.

Zavattaro, S. (2014). Organizational implosion: A case study of Detroit, Michigan. Administration \& Society, 46(9), 1071-1091. http://dx.doi.org/10.1177/009539971 4554681. 